\title{
Funeral rites, queer politics
}

\section{Journal Article}

\section{Author(s):}

Wagner, Roy (1)

Publication date:

2006

Permanent link:

https://doi.org/10.3929/ethz-b-000121663

Rights / license:

In Copyright - Non-Commercial Use Permitted

Originally published in:

Theory and Event 9(4), https://doi.org/10.1353/tae.2007.0014 


\title{
FUNERAL RITES, QUEER POLITICS
}

\author{
ROY WAGNER
}

\begin{abstract}
This paper builds on Jean Genet's funeral rites and on psychoanalytic theory to construct a model for a psycho-political technique. The paper then confronts the model with contemporary political struggles in the contexts of the Israeli-Palestinian conflict and of AIDS. We find that the technique we articulate is not only identity shattering (hence queer), but also contingent, temporary and unstable. Moreover, this psycho-political technique operates below micro-politics: it depends on distributed, fissured subjectivities; it therefore cannot be adapted to a political discourse where fully fledged subject positions are supposed. In some sense, we admit, this unstable 'nano-politics' is bound to eventually fail. We then discuss what might be the telos of, and motivation to engage in, such queer, pre-subjective, psycho-political technique.
\end{abstract}

\section{Executioner adoration syndrome \\ A well-known Jewish hereditary disease Don't get excited. ${ }^{1}$}

Genet's Funeral Rites was published 52 years ago. It is a sinister and bitter book. But since sinister and bitter days are here now, it is fitting, so it seems, to consider it still. The novel's bitterness is inevitable. Jean, the narrator, has lost his lover, resistance hero Jean D., in the final days of the liberation of Paris from Nazi occupation. How can one not be left with a bitter taste having devoured him - the dearest and only lover who ever loved me? Indeed, as Jean assures us, to eat a youngster shot on the barricades, to devour a young hero, is no easy thing (17-18) ${ }^{2}$. But before we conclude our grief by feasting on the dead, I would like to discuss what it is that may happen between the time a love is lost, and the time when we will have incorporated it into our minds and flesh.

What happens in Genet's Funeral Rites between loss of love and incorporation of the dead happens across an elaborate complex of identifications,

I thank Yehonatan Alshekh, Dr. Lyat Friedman, and Prof. Adi Ophir for their comments on earlier drafts of this paper.

${ }^{1}$ Talkback no. 121 to Yitzhak Frankenthal, "Arafat, get well soon", Ynet, October 30, 2004, http://www.ynet.co.il/articles/0,7340,L-2997192,00.html (Hebrew).

${ }^{2}$ Page numbers in parentheses refer to Jean Genet, Funeral Rites (Bernard Frechtman, trans., Grove Press, 1969). I apply the convention of using boldface to mark quotations. Italics in quotations are always in the original. 
desire and grief. We will attempt to articulate these events in terms of Freudian analyses of mourning and melancholia and of the ethical problems that such analyses raise (Butler's revisions, among others, will play an essential role). Between loss and incorporation, we will discover, the novel's subjective array tries to escape melancholia by deferring and displacing identification from the lost love to its mortal enemies.

Our reading will highlight the power potential inherent to this psychopolitical technique through various case studies (relating to the IsraeliPalestinian conflict and AIDS). In the gap between loss and incorporation we shall find a political technique which is identity shattering (hence queer), which is operated across and below the level of the subject, a level underlying micro-politics, a sort of 'nano-politics'. At this level political techniques arise contingently through unstable fissures in subjective surfaces, which they temporarily re-form. Such technique therefore cannot be adapted to a political discourse where fully fledged subject positions are supposed. Between loss and incorporation we find wedged an exploration of the ethics, eschatology and motivation to engage in contingent, temporary and subsubjective political techniques.

\section{Which DREAMED IT?}

Here we describe Funeral Rites' distributed subjective array

The plot of the novel, the network of relations between events and characters, is realized in the elementary structures of intercourse. Around the narrator, Jean (the namesake of Jean Genet), and a small nuclear family (mother Giselle and sons Paulo and Jean D.) revolves a complex network of sexual relations. 


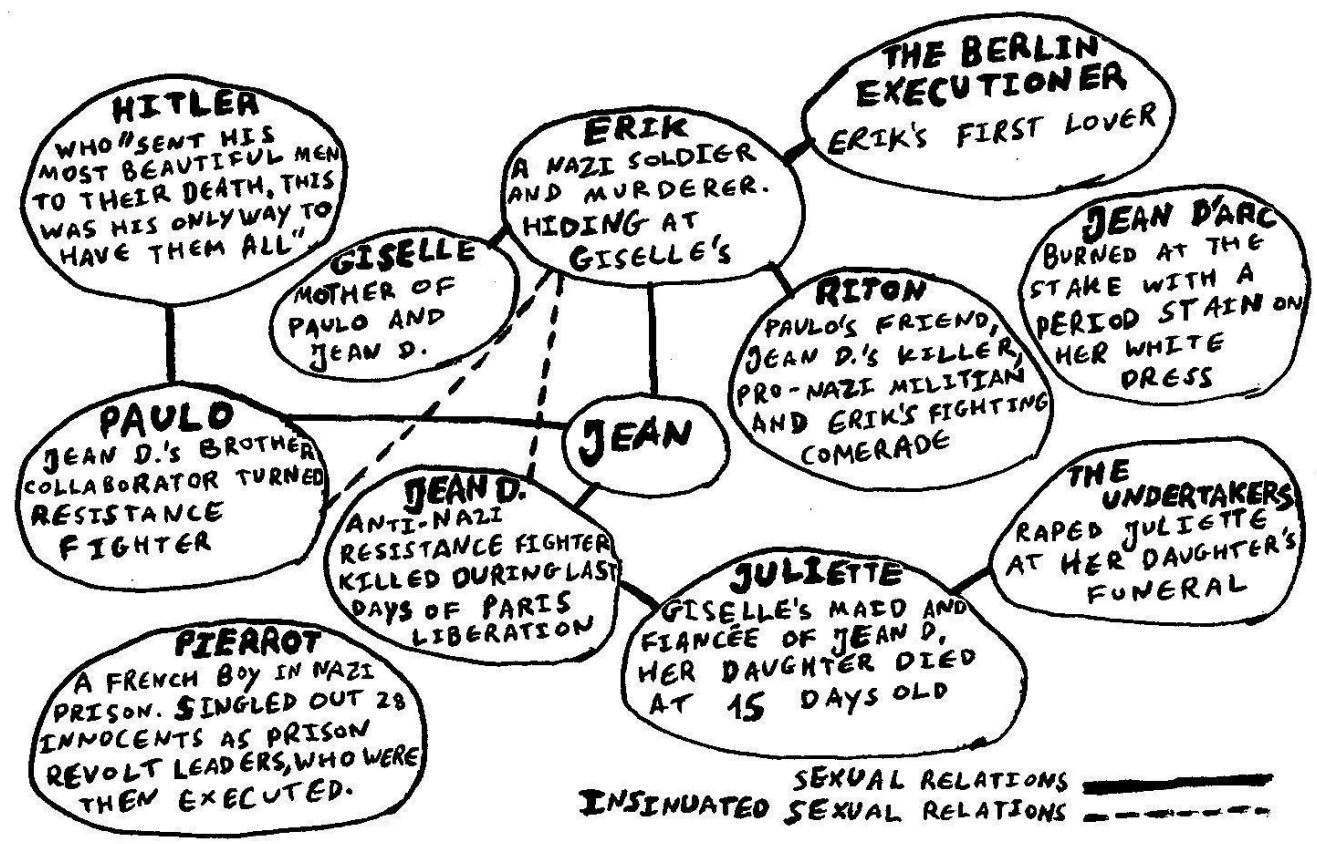

(Characters and relations in Funeral Rites. I do not distinguish here 'real' from 'fantasized' sexual relations, because the novel does not make such distinction).

But the plot is also construed through the rhizome of Jean's identifications with Nazi soldier Erik, with Hitler, with French collaborator Riton, with traitor Pierrot, with Jean D.'s half-brother Paulo, with national heroine Jean d'Arc, as well as through the assimilation of the dead hero Jean D. into the soul of Jean. These identifications, along with frequent cuts between narrative segments, are patched together in disharmony, roughly sewn by the hands of an artisan who sees no need to bother the reader with virtuosity.

For example, the four events described below ( Jean/Erik's stroll by the monastery, Jean's jealous fit, the death of Jean D., and Paulo's visit to Riton), which are far apart in time and place, are compactly welded together into a single paragraph. No doubt to wander about near an old monastery at the edge of a torrent, I had assumed the form of Erik, his grim face, and I camouflaged myself in the mist that always emanates from a gloomy hero. I felt protected by the fabulous power of the Reich. Nevertheless, I was aware of the sharp, luminous presence within me of Jean Genet, mad with fear. But perhaps I had never been so aware of myself as at such moments. 
When I kept Jean clinging by the teeth to the muzzle of my revolver, fear also shrank my center of consciousness by making it more acute. The fear of firing was combating the fear of not firing. Jean was living his last seconds more than I. Anyway, Riton's peace was definitively restored, one morning, ten days later, when he was called to the guardroom. Someone wanted to see him right away. It was a civilian. "Oh! Paulo!" (225-226).

And in yet other times and places, not only events, but characters are welded together as well; the border between voices is breached. When Riton reached to feel between Erik's legs, he parted his lips. He stayed that way for a few seconds, straining his mind so as to be fully aware of his joy. But within just half a page the third person narrative description of Riton is given up for a first person statement in the narrator's voice: I prejudged its splendor in action and imprisoned it, sleeping little girl that I was, in my big ogre's paw (153-154).

In that alone there's nothing new. The cutting and pasting of voices and events is to be found, in different degrees, throughout Genet's work. But in this novel the conundrum is inevitable. The novel deals with Jean's grief over his lover, resistance fighter Jean D., who dies during the final stages of the Parisian liberation uprising. Jean, the narrator-author, is bound to be displaced, because the text he writes is meant to decompose the gleam of light (composed mainly of love and pain) that is projected by my grieving heart (13), and because his story is a story only if this is a fitting title for the prismatic decomposition of my love and grief (22).

This decomposition, this chaotic system of voice and identity displacements, the statement I shall publish the novel so that it may serve Jean's glory, but which Jean? (164), all resonate Alice's question as she wakes from her journey Through the Looking Glass: Which dreamed it? Jean's response could hardly be any simpler than Alice's You see, Kitty, it MUST have been either me or the Red King. Jean's response to the question which flows through the entire novel, his response to the question but which Jean? must cut across the entire distributed subjective array of the book.

Now the question, which I shall confront with the novel, is not "what does it say?" nor "how does it work?" but "what can we do with it?". Given this stance, the response to the question which Jean? is charged not only with explaining, but also with doing. The narrator's name, 'Jean', the most banal name in French, could not possibly carry this weight. Neither can 'Jean Genet', regardless of whether he be the novel's author or the 
one present mad with fear in the heart of narrator-Jean. In order to come up with a name which is up for the task, in order to set Jean apart from the underground fighter Jean D., and in order to recall the German identification of prismatic-decomposition-Jean (identification with Nazi Erik and Hitler, with their collaborators Riton and Pierrot), we shall refer to the one-for-the-glory-of-whom-the-novel-is-published as does Nazi Erik, as Erik refers to our Jean just a few lines before Jean wormed his way into Erik's past (36), just a few lines before Jean assumes Erik's voice: we shall call him “Djian”. 'Jean Genet' Erik would likely pronounce 'Djian Dgene'. Therefore I decide here and from this moment on to give the presumed and collective author of Funeral Rites the German name 'Djian Dg.', which shall be regularly replaced by the Hebrew burr Djondge.

\section{IDENTIFYING AWAY}

We follow the displacement of melancholic identification from the lost love to its mortal enemies

Jean explains: little by little I became terribly afraid that since the friendship towards the dead Jean D. would have no external object on which to expand itself it might consume me by its fervor and cause my death. Its fire ... would, I thought, turn against me, who contain and detain Jean's image and allow it to merge with myself within me (28). To put things in Freud's confident jive: There is no difficulty in reconstructing this process. An object-choice, an attachment, of the libido to a particular person, had at one time existed; then, owing to a real slight or disappointment coming from the loved person, the object-relationship was shattered. The result was not the normal one of a withdrawal of the libido from this object and a displacement of it onto a new one, but something different, for whose coming-about various conditions seem to be necessary. The object cathexis proved to have little power of resistance and was brought to an end. But the free libido was not displaced on to another object; it was withdrawn into the ego. There, however, it was not employed in any unspecified way, but served to establish identification of the ego with the abandoned object. The shadow of the object fell upon the ego, and the latter could henceforth be judged by a special agency, as though it were an object. In this way an object-loss was transformed into an ego-loss and the conflict between the ego and the loved person 
into a cleavage between the critical activity of the ego and the ego as altered by identification ${ }^{3}$.

Jean invests his libido is Jean D. Jean D. dies. Jean's libido, instead of being invested in someone else, is redirected inwards. An identification is formed between Jean and Jean D. The conflict between Jean and Jean D. is converted into an internal conflict. This conflict is the prismatic decomposition which progenerates the hypothetic Djondge, whom we have baptized two paragraphs ago.

How clear and reassuring! ${ }^{4}$ Except that the melancholic process which in Freud's text is fully accomplished (The result was ... the free libido was not ... it was withdrawn ... the shadow of the object fell ... an object-loss was transformed ...), in Djondge's text is still only a virtuality ( since it would have ... would consume me ... would lead ... would return ...). Indeed, eventually identification will be accomplished. Eventually, Jean will live through me. I shall lend him my body. Through me he will act, will think (75), and indeed, the writing process is a process by which $\mathbf{I}$ am assimilating Jean, I am digesting him (129). But this melancholic process is only accomplished as such at the end of the novel, when Djondge is able to place in his mouth the lice which Jean D. had left between Erik's thighs, when he can finally eat the flesh of the tenderest body (that of Jean D.) without danger or remorse, so that I can assimilate it into mine, can take the best morsels of the fat with my fingers, keep them in my mouth, on my tongue, without disgust, feel them in my stomach, and know that their vitals will become the best of myself (247).

The concern of this text, however, is not the accomplishment of the melancholic process. My concern here is the gap, the moments which separate object-loss from an accomplished melancholic identification. This gap is a site of potential. And this site of potential, along with the manners in which it can be actualized before it is converted into a feast of incorporation, are precisely the issues I propose to lay out for a detailed review in this text which you read.

The road to the totemic feast is long and tortuous, so long and tortuous indeed, that its end, the assimilation of Jean D. into Djondge, may appear infinitely removed. Along this route one can hear Djondge ask (referring to

\footnotetext{
${ }^{3}$ Sigmund Freud, "Mourning and melancholia", The standard edition of the complete psychological works of Sigmund Freud (James Strachey, ed., Hogarth Press and the Institute of Psycho-Analysis, 1953-1974): Vol. XIV, 248-249.

${ }^{4}$ And how reassuring it is that we have psychoanalysis, a discipline which science cannot yet dispose of, and which is still widely exposed to parasitic intervention!
} 
Erik, the Nazi soldier): Was it possible that in my personal life I was accepting without anguish one of those against whom Jean had fought to the death? (17). The response comes promptly. Since Erik's force and vigor compensated for what (despite great austerity) was too frail in Jean's grace, I have ever since made great efforts to live Erik's life as a Berlin youngster (23). Later in the text Djondge will identify himself as Hitler, castrated by a 1917 bullet, lying with boys, and assume his voice; he will say: My soul visited Pierrot (181), and in a moment of generosity towards a prison officer will assume Pierrot's voice to turn in 28 innocent alleged uprising leaders for execution; he will proclaim I have the soul of Riton (116), and assume the voice of this pro-Nazi militia boy as well. Indeed, above all, the most important character glorified by the account of my grief and my love for Jean D. will be that luminous monster, Riton, who is exposed to the most splendid solitude, the one in whose presence I experience a kind of ecstasy because he discharged a burst of machine-gun fire into Jean D.'s body (161).

Throughout the novel, as in the last quote, the ultimate identification with Jean D. appears to be deferred in favor of identifications with the enemies of Jean D., even Jean D.'s own murderer, Riton. This murderer is discovered on the silver screen, in a news reel. A militiaman had just appeared on the screen, a kid of sixteen or seventeen ... The kid was skinny but good-looking. His face had suffered. It was sad. It was trembling. One would have thought it expressionless. His shirt was open at the neck. There were cartridge loops on his belt. He was walking in socks too big for him. His head was down. I felt he was ashamed of his black eye. In order to look more natural, to deceive the paving stones in the street, he ran his tongue over his lips and made a brief gesture with his hand which was so closely related to that of his mouth that it traced his whole body, puckered it with very subtle waves, and that immediately made me think the following: "the gardener is the most beautiful rose of his garden." (53).

Djondge decides to cast Riton in the role of Jean D.'s murderer. My hatred of the militiaman was so intense, so beautiful, that it was equivalent to the strongest love. No doubt it was he who had killed Jean. I desired him. I was suffering so because of Jean's death that I was willing to do anything to forget about him (54). Who shall Djondge love more? The same rivers of love poured over 
Riton, yet not a drop was withdrawn from Jean. I was preserving both youngsters under the double ray of my tenderness (57). But in order to dispose of the libidinal investment in Jean D., Djondge confers him upon Riton: I gave him to you, Riton. Love him dearly (58). And for the same reason, the more Jean's soul inhabits me - the more Jean himself inhabits me - the fonder I shall be of cowards, traitors, and petty no-goods (98). Even the words of love, which Jean D. offered him, Djondge places in Riton's mouth: "I now have the impression I love you more than before." This phrase was offered to me three months ago by Jean, and I place it in the mouth of a militiaman whom a German soldier has just buggered. Riton murmured: "I now have the impression I love you more than before." Erik did not understand (254).

\section{DeAth Before identificAtion}

Incorporation of the dead lover must be deferred; the price is a direct onslaught against the symbolic order

The ending will be a good one, as Djondge explains: We know the command contained in my grief: do what is good. My taste for solitude impelled me to seek the most virgin lands. After my disappointing setback in sight of the fabulous shores of evil this taste obliges me to turn back and devote myself to good (168-169). In the end melancholic identification will be accomplished in a Freudian, Christian, patriotic gesture. Finally, Jean appeared from somewhere or other, dead and naked. Walking on his heels, he brought me his corpse, which was cooked to a turn. He laid it out on the table and disappeared. Alone at the table, a divinity whom the negroes dared not gaze at, I sat and ate. I belonged to the tribe. And not in a superficial way by virtue merely of my being born into it, but by the grace of an adoption in which it was granted me to take part in the religious feast. Jean D.'s death thus gave me roots. I finally belonged to the France that I cursed and so intensely desired (248).

But this ending is of little interest to me as yet. I am concerned here with the time between loss of object and the accomplishment of melancholic identification, between death and the end, that space of time in which $\mathbf{I}$ have been feeling a kind of excitement which, cloaked by the alibi of Jean's glory, has been plunging me into a more and more intense and more and more desperate life, that has been impelling me 
to greater boldness. And I feel I have the strength not only to commit bolder burglaries but also to affront fearlessly the noblest human institutions in order to destroy them. I'm drunk with life, with violence, with despair (169).

Throughout the journey to greater boldness, Djondge finds it difficult to handle the funeral rites which gave the novel its title. He cannot bear their triviality. The undertaker's assistants took the coffin, and I followed the black-clad family. Someone loaded the hearse with wreaths the way one garners bundles of hay. Each action wounded me. Jean needed a compensation (27).

The symbolic order of the ceremony leads the way to a more radical symbolism. Just as in prison You're allowed one package a week. Whether it's a coffin or a box of matches, it's the same thing, it's a package, so in Djondge's pocket a box of matches and a coffin are the same. That's why I have a little coffin in my pocket (30), and that's also why I was performing in my pocket, on the box that my hand was stroking, a diminutive funeral ceremony as efficacious and reasonable as the Masses that are said for the souls of the departed, behind the altar, in a remote chapel, over a fake coffin draped in black (33). The arbitrariness of the symbolic-ceremonial order is such that even Sarah Bernhardt could have appeared in the form of a small box of safety matches (26) without betraying her enthusiastic fans. And from there it is but a short way to the moment when nothing prevented me from seeing in the old woman and the garbage can the momentary and marvelous figure of Jean (75).

The popular, spontaneous, authentic memorial erected by the people of Paris at the place where Jean D. died, fails to accommodate Djondge's mourning as well. Poor things. Mustn't ask who it's for, says a woman passer-by, who put the bunch of ridiculous yellow marigolds into a rusty can in which there were wilted red roses (47) under the tree where Jean D. was killed. And what if I erased it? asks Djondge, hoping that erasing Jean D.'s memorial inscription will wipe out the death of Jean D. as well. But he knows that the Parisian crowd would not allow it. I would be depriving them of a dead person, and above all a dead person who was dear to them by virtue of his being dead (46), he explains. And since, on the one hand, dismantling the decomposing altar would enrage the angry mob, but, on the other hand, this decaying monument was to blame for Jean's being kept on earth, since it was because of this decaying pile that he was unable to dissolve absolutely 
into the azure (49), Djondge is left with no other choice but to dissolve the symbol into pure voice, an empty form. He reads and re-reads the inscription "Here that he was killed" He-re, He-re, He-re, He-re. That he was killed, that he was killed, that he was killed, that heels killed, that heels killed... (47). The only hope Djondge is left with, is that if you turn your back to the memorial, and then turn back quickly enough, you would discover that things had disappeared, and you with them (48).

Freud explained that during the melancholic process occurs an inwardwithdrawal of both the libidinal investment in the lost object and the conflict with that lost object. Slavoj Žižek provides us with a further explanation, this time for Djondge's attempt to disintegrate the symbolic-ceremonial order. In the terms of dealing with the dead, he writes, one should, perhaps, against the work of mourning as well as against the melancholic attachment to the dead who return as ghosts, assert the Christian motto "let the dead bury their dead." The obvious reproach to this motto is, What are we to do when, precisely, the dead do not accept to stay dead, but continue to live in us, haunting us by their spectral presence? One is tempted here to claim that the most radical dimension of the Freudian death drive provides the key to how are we to read the Christian "let the dead bury their dead": what death drive tries to obliterate is not the biological life but the very afterlife - it endeavors to kill the lost object the second time, not in the sense of mourning (accepting the loss through symbolization) but in a more radical sense of obliterating the very symbolic texture, the letters in which the spirit of the dead survives ${ }^{5}$. These letters, so powerful, are exactly those by fault of which, if Djondge tried to repeat aloud the words that Jean D. said, his sentences, the bulging poems he wrote, there would be danger of giving Jean D. body within my body (62).

The violent death drive carries Djondge along with it. First dies the future. Since my life no longer has meaning, since a gesture denotes nothing, I want to stop living. Even if this decision is nullified and renewed every single moment, it prevents me from using the future. Everything must be done within the moment, since the next moment I shall be among the dead, squatting in the field of honor and talking to Jean. Every empty gesture that makes me think life will continue either betrays my wish to die or gives offense to Jean, whose death should lead to mine by means of love.

\footnotetext{
${ }^{5}$ Slavoj Žižek, Organs without bodies: Deleuze and consequences (Routledge, 2004): 13.
} 
That is how I lace my shoes, and the gesture quickens him. One doesn't wear shoes among the dead. I am therefore so detached from things as the condemned men I used to see in prison (101). Following the future, the entire symbolic order crumbles; our acts are wrapped in an aura of weariness and regret that make the acts seem false - only a tiny bit false, true on the whole, but false since they do not fully satisfy us (114).

That is precisely where and how a more and more intense and more and more desperate life, that has been impelling me to greater boldness (169) emerges. It emerges from the gap between the symbols and the place they occupy. This gap, which constitutes the power that symbols bestow, a gap which is nothing other than symbolic castration, is exposed and disfigured. Symbolic series break loose and run amok. Jean D. becomes a blooming branch, then placed into the trash-can which used to represent him, draped in white, and then explodes, dispersing a spray of glass, hair, stumps, peels, feathers, gnawed cutlets, faded flowers, and delicate eggshells (218). This is the opportunity I'm tracking down. This is the moment I wish to seize. Here, perhaps, we can find a violence which is law-destroying, which boundlessly destroys, which expiates, which strikes, which is lethal without spilling blood ${ }^{6}$.

\section{IT DOESN'T HAVE TO BE LIKE THAT}

Here we recall the contingency of displacing and deferring melancholic identification

But before we seize the opportunity, we must acknowledge its rarity. In Freud's Mourning and Melancholia, mourning is the healthy and normal substitute for melancholia. In mourning, reality's orders to give up the investment in the lost object are carried out at great expense of time and cathectic energy, and in the meantime the existence of the lost object is psychically prolonged. Each single one of the memories and expectations in which the libido is bound to the object is brought up and hypercathected, and detachment of the libido is accomplished in respect of it. Why this compromise by which the command of reality is carried out piecemeal should be so extraordinarily painful is not at all easy to explain in terms of economics. It is remarkable that this painful unpleasure is taken as a matter of course by us. The fact is, however, that when the work

\footnotetext{
${ }^{6}$ Walter Benjamin, "Critique of Violence", Selected Writings (Marcus Bullock \& Michael W. Jennings, ed., Belknap Press, 1996-2003): Vol. 1, 297.
} 
of mourning is completed the ego becomes free and uninhibited again $^{7}$.

This optimistic narrative loosens its hold six years later, when in the Ego and the Id Freud states that We succeeded in explaining the painful disorder of melancholia by supposing that [in those suffering from it] an object which was lost has been set up again inside the ego - that is, that an object cathexis has been replaced by an identification. At the time, however, we did not know how common and how typical it is. Since then we have come to understand that this kind of substitution has a great share in determining the form taken by the ego and that it makes an essential contribution towards building up what is called its 'character' ... it may be that this identification is the sole condition under which the id can give up its objects ${ }^{8}$.

After several years of hoping to completely disengage from the lost object's grip, Freud accepts the necessity to interiorize some lost objects, along with the ambivalent conflicts we bear towards them, as otherwise we could never let them go. The multi-faceted nature of the subject and its internal conflicts are no longer pathologies, but form the very essence of personality.

However, Freud's Mourning and melancholia quote does not mean that the counter-attack against melancholic identification, which Djondge goes through, is a necessary one. Djondge is trying to fight off melancholic identification. Djondge is trying to avoid incorporating the dead Jean D. Djondge is trying to displace identification towards the enemies of Jean D. This long and exhausting struggle, which goes all the way until it collapses into the resignation of a totemic feast - the intimate ceremony where Djondge could have finally cut Jean D.'s corpse up in a kitchen and eaten it (32) this vain struggle is not an unavoidable one.

Two characters in the novel demonstrate that the struggle against melancholic identification is not unavoidable. The first is the maid, Juliette, whose daughter (perhaps the daughter of a French colonel, perhaps the daughter of Jean D.) dies at the age of 15 days. The dead daughter used to be nothing but a kind of excrescence of foul ruddy flesh detached from its mother's body. Her memory appears as a small, shriveled corpse

\footnotetext{
${ }^{7}$ Sigmund Freud, "Mourning and melancholia", The standard edition of the complete psychological works of Sigmund Freud (James Strachey, ed., Hogarth Press and the Institute of Psycho-Analysis, 1953-1974): Vol. XIV, 245.

${ }^{8}$ Sigmund Freud, "The ego and the id", The standard edition of the complete psychological works of Sigmund Freud (James Strachey, ed., Hogarth Press and the Institute of Psycho-Analysis, 1953-1974): Vol. XIX, 28-29.
} 
clinging monstrously to one of her boobs by its nails and dead mouth (115). These facts turn the maid's identification with the daughter into identification with an excretion, into self-annihilation. Now since the maid's accomplishment of identification with the almost inanimate creature, her digestion of the dead daughter, is complete (she wonders: It's annoying that kids die and have to be buried. Why not make soup of them? It would boil down into stock, and make a nice meat soup (113)), the unavoidable result is the maid's occupation of the position of the dead person who was solemnly walking the road of the living, for the last time ... a dead yet living person on the way to the grave (112). And therefore, "If the dog throws a stone at me," she said to herself, "I'll bring it back in my mouth." (114).

Instead of dismantling the symbolic order, the maid gives into it completely, passively resigned. when her shoe lace is undone, she does not tie it back, as it would not have been proper for her to put her foot on a stone during the procession, for such a gesture, in addition to immobilizing you in the jaunty posture of a very proud lady going up a flight of stairs, distracts you from your grief (or from everything that should signify it, which is even more serious) by interesting you in the things of this world. The rites allow only a few gestures; drying one's tears with a handkerchief. ... You can wrap yourself in your crape (112).

The next character to identify with a dead object without a fight is Riton. Out of hunger, he kills and eats a cat. He then felt in his flesh the presence of a cat, a cat so well assimilated that at times he was afraid it could be heard miaowing and purring. Riton does not mind the assimilation. On the contrary, he fears that the cat might emerge from him and go off in its new form (of cat or devil) with part of his flesh (120). The day after eating the cat, following a night of headaches, indigestion and prayers to the cat, Riton joins the pro-Nazi militia. His movements were so nimble and sometimes so nonchalant that he himself thought occasionally that he was actuated by the cat he carried within him (162).

The concern of this text is the attitude against melancholic identification, which Djondge assumes, and which the maid and Riton avoid. This text is concerned with the potential enveloped in the attempt to displace identification away from the lost object, and to defer the inscription of the conflict in the self. It is concerned with the potential which results from the deferral of the assimilation of the dead in favor of a hopeless and desperate attempt 
to identify with others - the sworn enemies of the object loved and lost even at the cost of destroying the entire symbolic order.

This paper is concerned with the route which takes the likes of Rami Elhanan, who lost his daughter in a Palestinian terrorist attack, from At first I was tormented with anger and grief; I wanted revenge, to get even all the way to It was clear to my wife and I that the blame rests with the occupation. The suicide bomber was a victim just like my daughter, grown crazy out of anger and shame ${ }^{9}$. Obviously, the incorporation of a dead daughter is unavoidable. Obviously, her posthumous constitution of her father cannot be fended off. It cannot be fended off even by recruiting her murderer, even by attempting to identify with his cause. But Rami Elhanan's technique, the technique of displacing and deferring the accomplishment of melancholic identification, this technique harbors in its course intensity, boldness, despair. This technique is the concern of this paper which you read.

\section{Judith Butler Restores the Symbolic order}

We follow Butler to observe how dramatic expression might heal the conflict with melancholic identification

Judith Butler devotes two papers to an analysis of melancholic identification and its ramifications. Melancholy, she succinctly states is both the refusal of grief and the incorporation of loss, a miming of the death it cannot mourn $(142)^{10}$, recalling the formative role of mimesis. But since Freud has already established that melancholic identification has a great share in determining the form taken by the ego and that it makes an essential contribution towards building up what is called its 'character', Butler infers that subjectivity relies on the confounding of such mimeses, and that the reflexive structure of subjectivity appears to depend upon the prior operation of melancholia. Moreover, the ego is also figured as having a voice through this process, and it appears imperative within melancholia that self-beratement be voiced, not merely to oneself, but in the presence of others (181). From within the Freudian text Butler extracts the claim that melancholic identification is not only responsible for the content and structure of the subject, but also for its initiation into language.

\footnotetext{
9

${ }^{10}$ The forgiveness project, http://www.theforgivenessproject.com/stories/ghazibriegeith-rami-elhanan
} 
The claim that melancholia constitutes the conscious subject has, of course, far reaching consequences. To understand them one must first distinguish between normal mourning and pathological melancholia. Freud points out more than one such distinguishing features. For instance, he states that in melancholia the relation to the object is no simple one; it is complicated by the conflict due to ambivalence towards the lost object, and that in melancholia countless separate struggles are carried on over the object, in which hate and love contend with each other ${ }^{11}$. But this distinction, which is the most relevant to this essay as it stands so far, is not the one on which Butler's focus rests.

We shall therefore direct our attention together with Butler to another distinction between mourning and melancholia: Just as mourning impels the ego to give up the object by declaring the object to be dead and offering the ego the inducement of continuing to live ${ }^{12}$ - we shall abruptly cut the quote here, and return to it later. The keyword of the quote, for Butler, is declaring. The primary distinction between mourning and melancholia is that in mourning the object is "declared" lost or dead, but in melancholia, it follows, no such declaration is possible (170). A somewhat deeper formulation is the following: In melancholia the ideal that the lost person represents appears to be unknowable; in mourning, the person, or the ideal that substitutes for the person and that, presumably, renders the person lost, is knowable (172-173).

The distinction between normal and pathological lies first, according to Butler, in declaring and knowing. One of the symptomatic ramifications of this state of affairs is that the speech of the melancholic, since it cannot explicitly state loss, is neither verdictive nor declarative (assertonic), but inevitably indirect and circuitous (186). And if we agree, as before, that this speech which takes the place of declaring the lost object and of knowing the lost person or ideal, if we agree that this indirect and circuitous speech is the subject's initiation into language and the origin of the consciousness' reflexive structure, then we should also agree that the stronger the inhibition against expression, the stronger the expression of conscience (183). However, since by the very definition of

\footnotetext{
${ }^{11}$ Page numbers in parentheses refer to the chapters "Melancholy gender / refused identification" and "Psychic inceptions" in Judith Butler, The psychic life of power (Stanford University Press, 1997).

${ }^{12}$ Sigmund Freud, "Mourning and melancholia", The standard edition of the complete psychological works of Sigmund Freud (James Strachey, ed., Hogarth Press and the Institute of Psycho-Analysis, 1953-1974): Vol. XIV, 256.
} 
melancholia to refuse a loss is to become it (187), this state of affairs cannot be maintained. Becoming loss is expressed in self-punishment. The melancholic effect of the inability to express grief can achieve suicidal proportions (148). And we might even expect a culturally prevalent form of melancholia (139).

To help us out of this strait (jacket) or vicious circle, Butler, like Žižek above, invokes the death drive, which is paradoxically necessary for survival; in mourning, the breaking of attachment inaugurates life (194); we must rage against the dead in order not to join them (193). But Butler, in opposition to the suggestion that Žižek was tempted to set forth, sees the breaking of attachment, namely the role of the death drive, not as a shattering of the symbolic order, but as the integration of the ego into it. The death drive cannot cause a break with the constitutive historicity of loss to which melancholy attests (194), she writes. Survival, paradoxically possible only thanks to the death drive, is a matter of avowing the trace of loss that inaugurates one's own emergence (195). Survival depends on avowing ${ }^{13}$. The emergence of collective institutions for grieving are thus crucial to survival, to reassembling community, to rearticulating kinship to reweaving sustaining relations (148). And we are made $\ldots$ all the more mobile when ambivalence and loss are given a dramatic language in which to do their acting out (150).

Butler brings up the grieving institutions of the AIDS names project quilt and Queer Nation's die-in demonstrations as such rituals, crucial to a community whose access to the usual grieving institutions is limited. The same idea is expressed by Khaled Abu Awad, a Palestinian whose two brothers were killed by the Israeli army: In this meeting between Israeli and Palestinian bereaved families I sat aside, and suddenly saw Palestinian and Israeli mothers sitting together and crying. I realized that everyone in that room suffered the same pain. Each told his own story - and it had an impact on me. They wanted to hear me too, and asked me to join and tell what I am going through, and suddenly

\footnotetext{
${ }^{13}$ You must avow to survive, says Butler. Which chimes not unlike: "You must confess to survive". Which brings to mind the dramatic language of Catholic confession, and the Incitement to Discourse. Have I gone too far? Most certainly (such a comment could have only taken place if confined to the margin, and immediately revoked). And yet some affinity between Butler's decree to speak a collective and explicit dramatic language (in order to survive!) and the clerical incitement to discourse is not all that disavowable. I hope that my unease over the next few pages while taking up Butler's unavoidable solution will clarify my claim for that affinity.
} 
I felt a need to share, and I got into it because I felt there wasn't a single person in the room who wouldn't understand or listen to me. I realized we had another language, a common language, which emanates from our pain ${ }^{14}$.

The prerequisites and consequences of the dramatic language solution, a "let's talk about it" solution — or rather a "let's make up a language to talk about it" solution — undergo a sharp and sobering analysis in Butler's text. Integration into the institutions of language (and hence of symbolic order), which Butler has just marked as an inevitable consequence of a healthy resolution of mourning, turns out to be a prerequisite for mourning as well. Having emerged from the melancholic process described above, the subject who might grieve is implicated in a loss of autonomy that is mandated by linguistic and social life; it can never produce itself autonomously (195). Unless this subject is allowed to implode, it cannot help but reintegrate back into the symbolic order. Indeed if the ego contains aggression against the other who is gone, then it follows that reexternalizing that aggression "uncontains" the ego (193), and makes it a part of social life. And as mourning is so indissolubly enmeshed into social "uncontainment", the process of mourning can never be complete, for no final severance could take place without dissolving the ego (196).

\section{Alienation}

The limits of dramatic expression therapy are drawn; we acknowledge the power implicit in displaced and deferred identification

A word of caution, however, is required when following Butler's reading of Freud (which is close, sharp and fertile). The quote which I abruptly cut a few paragraphs back, continues thus - so does each single struggle of ambivalence loosen the fixation of the libido to the object by disparaging it, denigrating it and even as it were killing it $^{15}$. An inconsistency arises, but it is not quite clear who fails to "consist" with whom. Butler claimed that no final severance could take place without dissolving the ego. Do Freud and Butler disagree concerning the

\footnotetext{
${ }^{14}$ Shira Hochman, "Forgiveness is made with love", nrg, August 12, 2004, http://www.nrg.co.il/online/15/ART/767/808.html (Hebrew).

${ }^{15}$ Sigmund Freud, "Mourning and melancholia", The standard edition of the complete psychological works of Sigmund Freud (James Strachey, ed., Hogarth Press and the Institute of Psycho-Analysis, 1953-1974): Vol. XIV, 257.
} 
possibility of complete severance? Or do they both agree that complete severance is possible, but disagree on whether anything would remain then of the ego? Or is the inconsistency actually between Freud's The Ego and the Id and his Mourning and Melancholia (an inconsistency, which is simply a narrow-minded term for the evolution of Freudian thought)?

Either way, both Butler's reintegration into the symbolic order of a dramatic language and the Freudian narrative's resolution of eventually letting go of the object, both these finalés which propose a therapeutic telos, become worrying in view of Butler's following remark: Within the formation of gay and lesbian identity, there may be an effort to disavow a constitutive relationship to heterosexuality ... Not only does such a strategy attribute a false and monolithic status to heterosexuality, but it misses the political opportunity to work on the weakness in heterosexual subjectivation and to refute the logic of mutual exclusion by which heterosexism proceeds (148).

This concern has important consequences as to staging the dramatic language in which to act out, a language burdened with the task of (re)forming the subject-order relations. What is this performance set to achieve? Is it enough simply to allow melancholy an expression and the ego uncontainment? Here is the moment where I wish to bring the strands together.

In Butler's reading, the subject is constituted by incorporating identifications and their conflicts. However, as long as these incorporations are not directly and explicitly (dramatically) confessed, the melancholic constitution of the subject becomes a dangerous pathology. A healthy subject must be a locus of incorporation/excorporation, under pains of stagnating into terminal melancholia or complete dissolution. But in order for incorporation/excorporation not to fall prey to the logic of mutual exclusion, we must carefully consider the manner of excorporation and its variety of possible effects. My suggestion is that Genet provides us with some methodological indications as to how to achieve an excorporation which is not bound to a restoration of mutual exclusion.

To sew things together, I will first quote a letter from Genet to Sartre, written around the time of the publication of Funeral Rites. In this letter Genet, somewhat clumsily, lays a proto-version of Butler's argument. Homosexuality (rather than subjectivity in general) is for him an identification with death. The homosexual (originally, "pederast") must excorporate this death under pains of madness. But in order to avoid real death, the excorporation must be sublimated into poetic expression. So far the similarities 
to Butler's line of thought are clear. But this poetic expression, according to Genet, is still death. Therefore, it has no political prospect. It is still bound, one might say, to a logic of mutual exclusion.

A way out of such sterile forms of expression, I believe, may be read into Genet's work via Djondge's technique, which we have labored to articulate: displacing and deferring melancholic identification with lost love. As this technique is never theorized by Genet, but only traced in his novel through the voices of Djondge, I cannot call upon Genet for a theoretical presentation of his technique for confronting the danger of mutual exclusion, which Butler warns us of. I will therefore quote a different theoretical manifestation of Djondge's technique, personified by yet another theatrical and political thinker.

Let's start then with the letter written by Genet to Sartre ${ }^{16}$, which sketches a theory of becoming homosexual (or "pederast"), and testifies to the morbid and sterile potential of a dramatic acting-out. I think it happens like this: after a certain shock, I refuse to live. But, incapable of thinking about my death in clear, rational terms, I look at it symbolically by refusing to continue the world. Instinct then leads me toward my own sex. ... I will not embody the principle of continuity. It is a sulky attitude. Slowly instinct leads me toward masculine attributes. Slowly my psyche will propose to me funereal themes. Actually, first I know I'm capable of not continuing this world in which I live, then I continue, indefinitely, the gestures of the dead. These funereal themes, they too demand to be active, accomplished, if not there will be an explosion of madness! The proposed themes symbolic of death will thus be very narrow (the extraordinary limitation of the pederastic universe) (suicide, murder, theft, all anti-social acts, capable of giving me a death that if it isn't real is at least symbolic or social - prison).

If one of these themes is active, in fact achieved, it will cause my real death. Therefore it's necessary that I achieve it only in the imaginative realm, but if it's in the imagination, this means on the level of the erotic life (endlessly started over, and pointless) or in daydreams that resolve nothing.

\footnotetext{
${ }^{16}$ This unpublished letter, probably dated from 1952, is translated into English in Edmund white, Genet - a biography (Picador, 1993): 441-443. I wish to thank Yehonatan Alshekh for referring me to this letter, and for his invaluable intellectual friendship.
} 
The only thing that remains then is to activate these funereal themes in the imagination and to accomplish them in an act: the poem. The functions of a poem, then, will be:

(1) To deliver me from a funereal theme that haunts me.

(2) To transform it into an act (imaginary).

(3) To remove what was singular and limited in the act and to give it a universal significance.

(4) To reintegrate my funereal psyche into a social reality.

(5) To put childhood behind and to arrive at a maturity that is manly, hence social.

But these sublimation and reintegration, which so far support Butler's therapeutic prescriptions, have a strikingly sterile effect. If a fag speaks intelligently sometimes of a social problem, it's because he imitates his fragmentary mind ... But in politics nothing new can be contributed by a homosexual.... He cannot think about the social problem in an original fashion (Gide and communism!). Yes, there is Walt Whitman (but you know very well that's just a lyrical outpouring without any positive content). Moreover, with respect to the homosexual lover, Genet deduces, I commission him to live in my stead, my heir apparent. The beloved doesn't love me, he 'reproduces' me. But in this way I sterilize him, I cut him off from his own destiny.

If we wish to apply Butler's dramatic language as more than just a symptomatic cure, more than just a barren reintegration into the social logic of mutual exclusion, if we wish to use this dramatic or lyrical language as a tool for empowerment, this language cannot be restricted to empathy and identification. For if it were so restricted, explains Brecht in the short organum for the theater, the audience would look at the stage as if in a trance: an expression which comes from the middle ages, the days of witches and priests. Seeing and hearing are activities, and can be pleasant ones, but these people seem relieved of activity and like men to whom something is being done ... they seem to be given to vague but profound sensations $(187)^{17}$. In order to prevent the passive trance of empathic-melancholy identification, and perhaps also

\footnotetext{
${ }^{17}$ Page numbers in parentheses refer to Bertolt Brecht, Brecht on theater (J. Willett, trans. \& ed. , Hill \& Wang, 1964).
} 
to bypass Genet's symbolic sterilization and Butler's logic of mutual exclusion, Brecht suggests alienation. True A[lienation]-effects, he claims, are of a combative character (277).

What is it which links identification with a sterile trance? What is this alienation which is of a combative character that can conquer sterility? And, most importantly, what can we do with it? There is a great deal to man, says Brecht in the short organum, so a great deal can be made out of him. He does not have to stay the way he is now, nor does he have to be seen only as he is now, but also as he might become. We must not start with him; we must start on him. This means, however, that I must not simply set myself in his place, but must set myself facing him, to represent us all (193). More concretely, in the conversation about being forced into empathy Brecht brings up Cicero describing how the Roman actor Polus played Electra mourning her brother. His own son has just died, and so he brought the urn with his ashes on to the stage and spoke the relevant verses 'focusing them so painfully on himself that his own loss made him weep real tears. Nor could anyone present have refrained from weeping at that point' I must say there is only one word for such an operation: barbaric $^{18}(270)$. This operation is barbaric since it limits the great deal which can be made out of man. Suppose a sister is mourning her brother's departure for the war; and it is the peasant war: he is a peasant, off to join the peasants. Are we to surrender to her sorrow completely? Or not at all? We must be able to surrender to her sorrow and at the same time not to. Our actual emotion will come from recognizing and feeling the incident's double aspect (271). Now, in order to produce such an alienation effect the actor has to discard whatever means he has learnt of getting the audience to identify itself with the characters which he plays. Aiming not to put his audience into a trance, he must not go into a trance himself. And that is why the theater must alienate what it shows (193).

The term used by Brecht, alienation, may be misleading. It covers, at least partly, over what we have described a few pages ago as Djondge's technique: the displacing and deferring of identification. In Alienation effects in Chinese acting Brecht explains how the performer's self-observation, an artful and artistic act of self-alienation, stopped the spectator

\footnotetext{
${ }^{18}$ This example adds another dimension to Butler's attempt to link drag and melancholic identification (page 145).
} 
from losing himself in the character completely, i.e. to the point of giving up his own identity, and lent splendid remoteness to the events. Yet the spectator's empathy was not entirely rejected. The audience identifies itself with the actor as being an observer, and accordingly develops his attitude of observing or looking on (93). Identification is not crossed out as such, but rather displaced. The portrayed individual is not the spectator but his neighbor (93). There is not the same automatic transfer of emotions to the spectator, the same emotional infection. The alienation effect intervenes, not in the form of absence of emotions, but in the form of emotions which need not correspond to those of the character portrayed. On seeing worry the spectator may feel a sensation of joy; on seeing anger, one of disgust (94). Into Butler's dramatic language therapy for melancholia, into the dramatic language which Genet describes as a locus of death and barrenness, Brecht launches Djondge's technique: displacing and deferring identification.

Let's recapitulate. Freud's resolution was simple: work the object out of your system. Even Djondge admits, eventually, that Tears have stopped flowing from my eyes. In fact, I see my former grief behind a mirror in which my heart cannot be deeply wounded, even though it is moved (164). Butler's resolution was symbolic: express mourning in a dramatic institution. That's how the maid, Juliette, who cooperates fully with the psychoanalytic text, processes her grief. When she woke up, late in the night, a moonbeam was shining through the window and brightening a patch on the threadbare rug. She stood up quietly, piously, laid the daisy on that grave. Then she undressed and slept until morning (248).

But both Freud's simple solution and Butler's symbolic solution don't tell us how to use these solutions in order to work on the weakness in heterosexual subjectivation and to refute the logic of mutual exclusion. Brecht and Djondge, I believe, offer a trajectory of possible refutation. But even if we follow Brecht, and express mourning using the alienating dramatic language of epic-dialectic theater, the impact of the death drive will still be much less radical than in the picture which Žižek was tempted to paint. Neither Butler nor Freud, not even Brecht, attempt to reach out for obliterating the very symbolic texture.

Instead of attempting to bring the melancholic crisis to a proper resolution through (terminable or interminable) reterritorialization into the symbolic order, Djondge seeks to fight melancholic identification while it is still under 
way. Djondge draws on the death drive not in order to cut loose the rock which pulls him down into a vortex (Freud's simple solution), nor to carry the rock together with a whole community in order to stay afloat (Butler's communal solution), but, like the mythical bird Jing-Wei ${ }^{19}$, to fill the ocean (the cruel ocean which had previously drowned her) with so many rocks, so that there no longer is an ocean, no longer a sea where lives can be lost.

\section{A methodological note}

\section{worth the consideration of those to whom it may prove worth considering}

Genet was our mannequin and case study. Freud, Žižek, Butler and Brecht supplied us with symbolic fabric. We have been patching, or quilting, a symbolic model for a psycho-political technique which operates across identities rather than within the micro-political field of a distinct self-conscious subject; this queer, 'nano-political' technique is the technique of Djondge: displacing and deferring melancholic identification.

Now we should attempt to apply our symbolic model; measure our quilt against our beds and our bodies; let our quilt fashion the bodies covered under it; let our quilt soak the scent, humors and fibers of the bodies which it tries to cover; vainly presume to measure our quilt against fixtures it could never hope to cover - answer the question "what can we do with it?". A quilt which remains clean, a non-applied symbolic model, are just not worth the effort.

\section{PARENTS OF DEAD CHILDREN}

\section{Israeli and Palestinian bereaved parents displace and defer identification}

\footnotetext{
${ }^{19}$ Yan Di had a favorite daughter named Nüwa who went out on a small boat to enjoy herself on the Eastern Sea one day. Unfortunately, a violent wind arose and mountainous waves immediately swallowed her boat, and she was drowned, never to be heard from again. Yan Di was grief-stricken, but even this great god had no power to bring her back to life. Naturally, Nuwa resented having to die so young. Her soul turned into a small bird called Jing Wei which bore some resemblance to the crow, except that her head was variegated in color, her beak was white and her claws were red. She lived in Fajiu Mountain in the north, and since she hated the cruel sea for having robbed her of her youthful life, she would regularly take a pebble or a twig in her mouth, fly out over the sea, and drop it in. By so doing she hoped to fill in the sea so that no more lives would be lost in it. Even though the sea assured her that this would be a futile task, she never gave up on her effort: she would drop her stone or stick into the sea, shout at it, and return to the mountain for more objects to drop, back and forth, never resting. Quoted from Jan \& Yvonne Walls, Classical Chinese myths (Joint Publishing Hong-Kong, 1984): 29.
} 
A well known psychological phenomenon:

The victim's identification with the aggressor

It is very patent when victims, after their release

praise the people who abducted them ${ }^{20}$.

This verse, a talkback to Yitzhak Frankenthal's newspaper article praising the leadership of the dying Yasser Arafat and wishing him good health, marks Frankenthal (until a few months before the time in which I write these lines the leader of the Israeli-Palestinian 'Parents circle — bereaved families forum for peace') as a person who displaces his melancholic identification from his dead son towards the enemy who killed him. As if it wasn't enough for Frankenthal's son to endure the agony of a horrible murder, here comes his own father (could he be his own flesh and blood?) and identifies with his torturers and murderers. Could there be a greater betrayal? ${ }^{21}$. The same talkback, stating that with these words you are an accomplice to the deaths of other sons, testifies to the alleged betrayal not only against Arik, Frankenthal's son who had been kidnapped and killed, but also against the entire 'nation'.

The betrayal enveloped in displacing identification towards the enemy is not unique to the forum's debunked-founding-father Frankenthal, but characterizes other forum members as well. Ghazi Brigeith, whose brother was killed at a checkpoint, writes: At first I was completely out of my mind - crazy with grief. There should be no forgiveness for the killers of innocents, and yet even then I saw the soldier as a victim of the occupation just as my brother was, just as I am still. Rami Elhanan, who lost his daughter in a suicide bombing replies, I don't forgive and I don't forget, but when this happened to my daughter I had to ask myself whether I'd contributed in any way. The answer was that I had - my people had, for ruling, dominating and oppressing three-and-a-half million Palestinians for 35 years. It is a sin and you pay for $\operatorname{sins}^{22}$. The attempt to displace identification produces here political action not because it annihilates melancholic selfberatement, but because it confronts melancholy with other identifications. An explicit link between a complex identification array, guilt and power is produced by forum member Muhamed Taleb Shacker: A person needs...

\footnotetext{
${ }^{20}$ Talkback no. 73 to Yitzhak Frankenthal, "Arafat, get well soon", Ynet, October 30, 2004, http://www.ynet.co.il/articles/0,7340,L-2997192,00.html (Hebrew).

${ }^{21}$ Talkback no. 284 to Yitzhak Frankenthal, "Arafat, get well soon", Ynet, October 30, 2004, http://www.ynet.co.il/articles/0,7340,L-2997192,00.html (Hebrew).

${ }^{22}$ The forgiveness project, http://www.theforgivenessproject.com/stories/ghazibriegeith-rami-elhanan
} 
power... to come to such a meeting... because perhaps someone is sitting here... my brother threw a rock at his son... A person must overcome something like that ${ }^{23}$.

For Frankenthal, whom the newspaper's website talkback writers diagnosed as suffering from Stockholm, Helsinki and Patty Hearst syndromes, the identification array is even more complex. In the documentary The son's legacy ${ }^{24}$, Frankenthal quotes his dead son saying if I were a Palestinian, I would attack Israeli soldiers. Melancholic identification with the son necessarily means therefore assimilating the son's identification with the enemy. And if, oppositely, Frankenthal were to displace his identification away from his dead son towards the enemy, he would still find himself identifying with the Palestinians. In such circumstances the displacement of identification is inevitable, and structurally imposed. So far I have described Djondge's technique of displacing and deferring melancholic identification as resistance to melancholic identification. In Frankenthal's case, melancholic identification and Djondge's technique overlap. To identify with his son is to identify with his enemy.

The impact of the overlapping between melancholic and displaced identification is a distributed subject, which is performed on the surface. As far as I am concerned the murderer is a murderer, says Frankenthal in the documentary. If I see him on the street, I'll try to kill him, no doubt, I am speaking as a father. But as a person trying to find peaceful solutions, I will be happy for every Hamas person or terrorist who joins the peace-camp and tries to act for peace. Frankenthal and a Palestinian forum member hold each other's dead son's picture in their wallets. But when Frankenthal visits a tent of Palestinians on a hunger strike for the release of Palestinian prisoners, he publicly speaks of the Palestinian mistake, of how force will not yield results and terrorism is the weapon of weak people. The almost violent conflict with the hunger-strikers erupts promptly, even though the pain is common to all. On another occasion, Frankenthal writes to the Jewish Gaza strip settlers following the suicide of a friend's son. The son committed suicide just after his best friend's death as a soldier in Gaza, and Frankenthal's text reads: Please, Brothers, do not regard us as your enemies, you are our brothers and we understand very well the meaning of peace. We understand that peace will only prevail if we make painful compromises. And just a few line later I rest the full responsibility

\footnotetext{
${ }^{23}$ From the documentary Tears of peace, http://www.theparentscircle.com

${ }^{24} \mathrm{BBC}$ news report, Son's legacy, http://www.theparentscircle.com/PressClippings.asp
} 
for this terrible bloodshed, where our children are killed in Netzarim (Gaza settlement) solely at your door, residents of Netzarim. I am sure that the Lord will know how to repay you properly ... Today you are the messengers of the devil ${ }^{25}$.

Does the agonizing ambivalence incorporated into his subjective array (array of power, array of identification) contribute towards what makes Frankenthal an undoubtedly powerful political person? Even today I am still convinced that there should be two separate cooperating organizations, rather than just one ${ }^{26}$, says Frankenthal in an interview. He refers to the Palestinian-Israeli division inside the forum, but his position is similar with respect to the division between members who lost their relatives in a terrorist or military action, and those whose relatives died in a military accident. This stand raises the question, whether the duplicate array in the following image (Left candle reads: "In memory of the Israeli

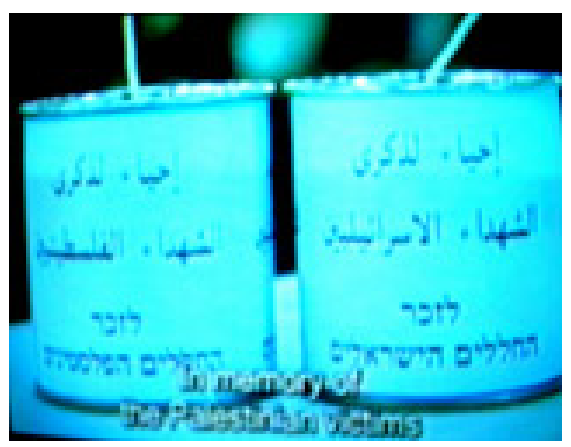

casualties"; right candle: "In memory of the Palestinian casualties")

is more politically effective than a unified front of one candle for all victims. Would a unified front sterilize the power potential of a distributed identification? Oppositely, do duplication and splitting necessarily form symbolic oppression, a binary reterritorialization of the real force which breaks from within displaced identification, a forcing into two of that which is not one?

If Frankenthal is cast into a structural trap of displaced identification, all the more so is true for the parents of dead soldier Daniel Hiller. Daniel so claim the authorities - killed himself during his military training. How can you identify with that? Identifying with a son who commits suicide is identifying with his choice of death; displacing identification from the

\footnotetext{
${ }^{25}$ Yitzhak Frankenthal, Letter to the Netzarim settlers http://www.mideastweb.org/frlettereng.htm

${ }^{26}$ Lily Galili, "It is not easy to lead bereaved parents", Haaretz, November 4, 2004, http://www.haaretz.co.il/hasite/pages/ShArtPE.jhtml?itemNo=497743 (Hebrew).
} 
suicidal son towards his enemy, is, yet again, nothing but identification with the son who chooses to kill (himself).

The conclusion reached by church fathers contemplating the son who sacrificed himself to himself, was a god with two physis but only one telos; a god who is one who are three who is one. Such analytic distantiation was not available to Daniel's parents, Daniella and Herman Hiller. Their choice of life forced them to displace their identification from allegedly-suicidal son towards the fearless-heroic son, the Karate champion, who had endurance, who would never do it, never in his life would he do it ${ }^{27}$, as his father puts it. But if the parents are to cross out their son's choice of death, the immediate candidate for the role of murderer is the army, which, especially in Israel, implicates the spirit of the nation. The cost of this choice, the parents' identification with the son who used to call his father a weak man, a loser, is to cast in the role of murderer the very objects which Daniel explicitly identified with: the army and the nation. The result is an agonizing conflict between the parents' identification with the son, and their refusal to identify with everything their son identified with. Herman Hiller, the father, recounts: I told him, Dani, we paid a heavy price (referring to the death of another child). I don't want to be there again, and pay a greater price. He told me, Dad, if everybody thinks like you do, who will go and fight for the country? We raised a child who loves his homeland and everything, and this was the mistake, this was the mistake, $1-0$ to the army ... It is better to be coward and alive than be a hero in a coffin. During the national memorial day minute of silence in honor of fallen soldiers, Herman tells his wife, Daniella, why are you standing, what are you standing for? I have nothing to be ashamed of, I am proud of my son. It's just that I'm ashamed of this country, the army, disgusted by the flag, and disgusted by the national anthem. I am disgusted with all of that. And along with denying the national order, the religious order crumbles too. All I do, cover my head, recite the mourning prayer and all, it's all for Dani. Apart from this I care for nothing ... it's only for sort of to show him respect, only for that, but except for that I will never have faith anymore. This faith is nothing. Here too the tension is patent between identifying with the son and rejecting the son's objects of identification, rejecting faith and the nation, who have allegedly taken the son's life.

\footnotetext{
${ }^{27}$ All quotes are taken from the documentary The Hillers, produced and directed by Sharon Attias, Israel, 2004
} 
This tension erupts when Daniella and Herman converse with another couple of bereaved parents, more than two years after Daniel's death. In reply to the other couple's decree you'll have to let him go. It won't do. It won't do. He's gone, Daniella bursts in tears and cries he's away, he's away, he didn't... he didn't... he's away, he will come back, I still have hope... You know, I'll tell you something extreme, how I've just felt? That he was coming for a visit. Identification is displaced away, and mourning is suspended.

The array of identifications gets even more complicated. Daniel died 17 years after his older brother, Armon, had died at the age of five. His younger sister is called Armona. Daniel's face is tattooed on Herman's shoulder, next to Armon's face. In tears of struggle, next to Daniel's coffin which Herman secretly dug out in the middle of the night, two years after Daniel's death, in order to force the army to renew the investigation into the circumstances of Daniel's death, next to the coffin which he himself carried into his own livingroom, the father says: I want to bury my son... my son properly, and not dirty, like they also did to me 19 years ago. This time it won't help them, they're wasting their time, they should know that this time I'm even willing to die and... if they break in forcefully I'll blow up the gas containers, I'll cut my throat, they're wasting their time. In the midst of the struggle Herman is bound into identification with two dead sons and death itself.

This impossible array is an invaluable source of power. As Herman Hiller brings Daniel's coffin into their home, Daniella is sitting on a chair, and with unimaginable force drags herself back into the world, lifting herself by her own bootstraps. I am strong... take a deep breath, let it out, she guides herself. And just before Daniel's autopsy Daniella prepares Herman for the encounter with his dead son's body, discussing with him what they are going to see, so that they can stand the experience. Against Herman's force, who enabled him to dig out his son's coffin with his own hands, there stands Daniella's force, who orders reporters around, publicizes her cause, and scolds a stereotyping writer who dared refer to her hands as callous.

The force which erupts from the complex identification array arises from Daniella and Herman alike, despite the marked difference in their attitudes to the symbolic order, or, more likely, precisely because of this difference. When Daniella sees a military helicopter flying towards the hospital where her son's body is stored, she says to her husband perhaps there are casualties. Herman answers so, what can I do about them? When a bereaved father arrives at the morgue to identify the body of his dead son, 
Daniella says, contrasting with her husband's apparent indifference, soldiers... soldiers... it rips my heart apart... poor, poor father. When the body of a Bedouin is wheeled into the morgue with his head uncovered, Daniella cries Did you see that? They don't even cover their heads. Even the reading of a horoscope is indulged by Daniella and refused by Herman.

The Hillers' extraordinary power obtains its objective. An independent pathologist is allowed to perform an autopsy. His findings match the army's suicide hypothesis. But the pathologist also finds that most of Daniel's internal organs had been secretly removed (probably for research purposes), and that the body had not been properly stitched after the original autopsy conducted by the state's pathologist. Now is the big war, we cannot be quiet, we have another story, says Daniella. During her son's second funeral she cries we are not in mourning, not performing the religious mourning rituals. You are invited to visit us at home, but we are not in mourning, we are only in struggle. Mourning is still suspended, and identification is left unresolved. Several weeks later Daniella and Herman Hiller demonstrate at the army headquarters in Tel-Aviv. Later still, an official committee rejects the findings of the independent pathologist concerning the stolen organs.

\section{Aids Coalition To Unleash Power}

The power implicit in deferred and displaced identification is put under the scrutiny of death

Let's follow Butler again to discuss the AIDS grieving institutions which lay out a dramatic language in which to act out. The question whether the dramatic language underlying these institutions is Aristotelian (based on empathy and catharsis) or epic-dialectic (based on alienation) is not something which needs to be decided in an either/or manner. It is clear that Djondge's technique emerges, at least briefly, to entangle in this multifaceted drama. The words of activists reveal occasions where identification is directed not at dead comrades and lost loves but at death and illness themselves. For instance, choosing to dispose of 'AIDS victim' and 'AIDS patient' in order to take up 'person living with AIDS' is a choice to integrate AIDS into the subject. AIDS is no longer a parasite or an external enemy, but is part of the being-with of a person. This identification is even more explicit in 'die-ins', which combine traditional 'sit-ins' with public displays of death. 
Instead of incorporating other victims, the lost objects of mourning, it is death, AIDS, the executioner, who is invited into the subject. A strong expression of this political technique can be found in the following ACT-UP NY banner:

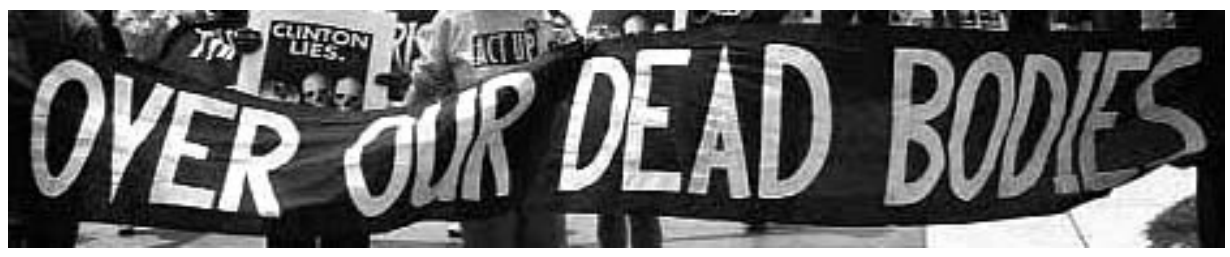

The banner-bearers ironically mark their own bodies as dead. This alliance can even be used against a third party:

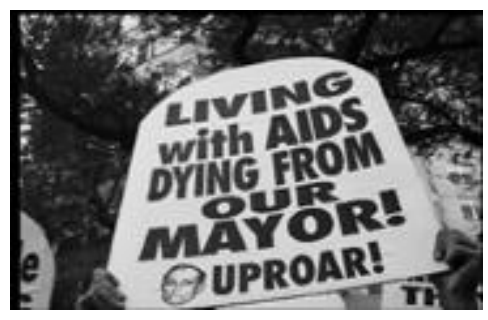

In Mark Fisher's funeral, Jon Greenberg states: Mark knew he was going to die. We, each of us, will also die. Mark's life and death, if it is to mean anything, cannot be trivialized by wishing it away or by pretending that there could be any other end. Yes, we are in pain. We have lost a precious powerful friend and colleague. But to avoid that pain by blaming it on someone else, robs us of our opportunity to experience and learn from a greater consciousness, a larger self, a fearlessness. Acceptance of our mortality — as Mark accepted his - makes it possible to live life fully, in spite of our fear; makes it possible to live life in real freedom because we are not afraid of the consequences of our actions. It is only after we see how trivial and illusory are the political, social, religious, and physical barriers of this world can we begin to liberate ourselves from our fears and find our true power, consciousness, action and fearlessness ${ }^{28}$. The acceptance-incorporation of death, the identification with the executioner at the expense of laying blame, is the realization of the very promise inscribed in the title 'ACT-UP', an acronym for 'AIDS Coalition To Unleash Power'. Djondge's technique, the technique of displacing and deferring melancholic identification is a technique of unleashing power. The melancholic technique of identifying oneself with lost loves and of raging

\footnotetext{
${ }^{28}$ ACT-UP NY website, http://www.actupny.org/diva/CBnews.html
} 
against the executioner is deferred in favor of assimilating the executioner (AIDS, death); it is deferred in favor of incorporating death's fissure of barriers, of releasing the energy of that fission, of detonating a psychic nuclear bomb.

It goes without saying that the pathos of Greenberg's speech is unstable. The force emanating from identifying with death rather than with the lost Mark is as provisional and fleeting as Djondge's attempt to displace identification towards the enemies of Jean D. Even the very eulogy quoted above (like Djondge's book) contains statements which expose other, melancholic identification tactics, not to mention significant attachments to the symbolic order. But the political technique which we contemplate here, Djondge's technique of displacing and deferring melancholic identification, is not presumed to annihilate melancholic identification altogether. Such presumption is self defeating, as Djondge's technique can only take place against a background of a disturbing melancholic identification . Djondge's technique of deferring mourning and displacing identification does not replace or foreclose melancholic identification, but rather suspends it, redirects it, redistributes it.

In our discussion of bereaved parents we found the most striking eruptions of force related to Djondge's technique (of deferring and displacing melancholic identification) in situations where the choice wasn't between identifying with lost love and with its enemies, but in situations where identifying with lost loves necessarily implied identification with an enemy. In a sense this is also the case in the context of AIDS. The lost love (lost lover) is quite often an accomplice to the contraction and transmission of disease and death to the mourning community. The lost love is often implicated in its own cause of death, and sometimes even that of the mourner. In some other cases, it is the mourner who is the transmitter of death to the lost love. Incorporating the lost love is, then, resigning it over to its mortal enemy. Clearly, in such situation melancholic identification is necessarily displaced towards identification with the executioner. The decomposition of the ontological division between a loved one and its nemesis, between infector and infected - this decomposition is the very process which Unleashes Power. Trying to force infectors and infected apart, on the other hand, is precisely the kind of strategy which reinstates the logic of mutual exclusion and reterritorializes power into the stale order of disempowering conflict.

As a result the unaccomplished melancholic process must linger on. Eventually, in his will, Greenberg too turns to melancholic identification and 
assimilation. The motto he left behind was I don't want an angry political funeral. I just want you to burn me in the street and eat my flesh $^{29}$ (the melancholic march of the maid behind the hearse carrying the corpse of her dead daughter, her wondering, couldn't we use the dead daughter to make soup? clearly demonstrates that there is no contradiction between eating the dead and escorting them serenely to their final resting place). And still, the provisional, fleeting effect of displacing and deferring melancholic identification, the effect of Greenberg's opportunity to publicly declare ... our right to be proud of our deaths ${ }^{30}$ for a few moments between Mark Fisher's funeral in 1991 and Jon Greenberg's funeral in 1993 - this effect cannot be dismissed as insignificant.

Butler's text does offer buds/traces of Djondge's queer political technique. She quotes from Homi Bhabha the idea that melancholia is a rebellion that has been put down, crushed, since the melancholic inverts against itself the indictment it would level against the other; this "incorporation" of the other is also, Bhabha notes, a "disincorporation of the master". Since in light of this incorporation of indictments against the master there is no longer any need for the presence of the master himself, melancholia contests the ideality of that authority precisely by incorporating it (190). Lingering on to this revolt is precisely what Djondge's technique is all about: hanging on to contestation while vainly attempting to defer the unavoidable incorporation - an ongoing state of indigestion.

The psychoanalytic symptom of this revolt is mania. In mania, the ego must have got over the loss of the object ..., and thereupon the whole quota of anticathexis which the painful suffering of melancholia has drawn to itself from the ego and 'bound' will have become available ${ }^{31}$. Nevertheless, warns Butler, mania marks a temporary suspension or mastering of the tyrant by the ego, but the tyrant remains structurally ensconed for that psyche - and unknowable (191-192). Mania, like melancholia, says Butler, has to do with not knowing. True, mania does have an exceptional status, as the ego has no break with the constitutive historicity of loss to which melancholy attests (except perhaps in the manic response, but Butler

\footnotetext{
${ }^{29}$ ACT-UP NY website, http://www.actupny.org/diva/polfunsyn.html

${ }^{30}$ ACT-UP NY website, http://www.actupny.org/diva/CBnews.html

${ }^{31}$ Sigmund Freud, "Mourning and melancholia", The standard edition of the complete psychological works of Sigmund Freud (James Strachey, ed., James Strachey, ed., Hogarth Press and the Institute of Psycho-Analysis, 1953-1974): Vol. XIV, 255.
} 
immediately reterritorializes by recalling that the manic response is always temporary) (194).

Likewise always-temporary is the psycho-political technique of Djondge. Any non-temporary solution is by definition ordered and structured. Any permanent solution requires the putting down, crushing, of the revolt which Bhabha has invoked - only to immediately put down, crush. Therefore even Jing-Wei, the mythical bird which expresses grief by casting stones into the ocean which had drowned her, the bird which illustrated for us Djondge's technique only a few pages ago, turns out to be constrained by an ordered ritual; even if she succeeds in filling in the sea with stones, the sea will just turn into another patch of level ground. Her violence is lawmaking (the law of repeatedly casting stones), it sets boundaries (flying between the mountains and the ocean), it brings about guilt and retribution (blaming the sea for her drowning and seeking to avenge her death) and threatens (since it can never win). One may find consolation in that, at the very least, it is not blood $\mathbf{y}^{32}$.

As Freud has established, melancholic identification institutes conflict between the different parts of the subject: those which identify with the lost object, and those which criticize it. Butler applies this very model to the concept of power itself. By withdrawing its own presence, power becomes an object lost — "a loss of a more ideal kind." Eligible for melancholic incorporation, power no longer acts unilaterally on its subject. Rather, the subject is produced, paradoxically, through this withdrawal of power, its dissimulation and fabulation of the psyche as a speaking topos. Social power vanishes, becoming the object lost, or social power makes vanish, effecting a mandatory set of losses. Thus, it effects a melancholia that reproduces power as the psychic voice of judgment addressed to (turned upon) oneself, thus modeling reflexivity on subjection (197-198). In fact, it would have been productive to supplant throughout the discussion the concept of "power" for the concept of "conflict" as it is presented by Foucault: Power is exercised only over free subjects, and only insofar as they are free. By this we mean individual or collective subjects who are faced with a field of possibilities in which several ways of behaving, several reactions and diverse comportments may be realized. Where the determining forces saturate the whole there is no relationship of power; slavery is not a power relationship

\footnotetext{
${ }^{32}$ Walter Benjamin, "Critique of Violence", Selected Writings (Marcus Bullock \& Michael W. Jennings, ed., Belknap Press, 1996-2003): Vol. 1, 297.
} 
when man is in chains. (In this case it is a question of a physical relationship of constraint.) Consequently there is no face to face confrontation of power and freedom which is mutually exclusive (freedom disappears everywhere power is exercised), but a much more complicated interplay ... it would be better to speak of an "agonism" - of a relationship which is at the same time reciprocal incitation and struggle; less of a face-to-face confrontation which paralyzes both sides than a permanent provocation ${ }^{33}$.

Taking into account Butler's conclusion that the power imposed upon one is the power that animates one's emergence, and there appears to be no escaping this ambivalence (198), one can reconstruct what animates the emergence of Djondge's technique. Displacing and deferring melancholic identification flood the subject with an array of identifications whose emergence is animated by power, namely by permanent provocation. The power potential of such a distributed subject, its potential to be actively audacious, is not to be dismissed.

\section{Djondge, Phallus, AND A FAIlure FORETOld}

Conclusion: we discuss the purpose of sub-subjective nano-politics which cannot last, and dissipate

All will end well. The end will be Christian and patriotic: the fathers will eat the sons, and Jean Genet will have his entire work published by Gallimard with an infinitely long foreword by Sartre. This end is the end of the struggle. This end is the accomplishment of melancholic identification. And even if this end is not a moment but an endless process (since identification is not a decision but a complex of performances and practices, which insists only if it is being repeatedly reaffirmed), still the struggle against identification, the running amok of the death instinct, the manic outbursts of unattached psychic energy - all these are destined to wither away.

Djondge's struggle too is strictly confined by the symbolic order. The symbolic order is what provides him with the permission to struggle in the first place. suddenly I understood the necessity of mourning symbols such as a black arm-band; they advise people to approach you with consideration, to be tactful with you, for you are the repository of a divinized memory (43). Without the black arm-band, without the

\footnotetext{
${ }^{33} \mathrm{M}$. Foucault, "The subject and power", in Michel Foucault: beyond structuralism and hermeneutics, ed. H.L. Dreyfus \& P. Rabinow (University of Chicago Press, 1983): 221-222.
} 
dedication commemorating the dead hero Jean DECARNIN on the coverpage, Djondge would not have had the temporary permission to host within him Nazis, traitors, militiamen, Hitler himself, and have it all published. And without the dead son, Yitzhak Frankenthal would not have had the opportunity to publish an article praising the dying Arafat in an Israeli daily newspaper. Moreover, the very struggle, this more and more intense and more and more desperate life, that has been impelling me to greater boldness (169) is symbolically cast in the form of a book. I realize that this book is merely literature, but let it enable me so to glorify my grief that it emerges by itself and ceases to be - as fireworks cease to be when they have exploded (178). But more avowedly than the granted permission and symbolic form of the project, the anticipated failure of the struggle against identification is attested by Djondge himself, when he states that the characters in my books all resemble each other. They live, with minor variations, the same moments, the same perils, and when I speak of them, my language, which is inspired by them, repeats the same poems in the same tone (97). The displacement of identification towards Nazi Erik and Riton, is, eventually, not a displacement away from identification with resistance hero Jean D., because Jean D., Erik and Riton resemble each other, and because the power relations between Erik and Riton resemble the power relations between identification with Jean D. and the insisting conflict towards him. I'm trying to present these characters (Riton, Erik, Paulo) to you in such a way that you see them lit up by my love, not for their sake but for Jean's, and particularly in such a way that they reflect that love (59).

When the pages turn to close the novel, after Erik fucks Riton, after Riton borrows from Jean D. his words of love to Djondge and offers them to Erik, no tenderness could have been expressed, for as their love was not recognized by the world, they could not feel its natural effects. Only language could have informed them that they actually loved each other (254). A love haunted by the specter of a certain unreality, a certain unthinkability, the double disavowal of "I never loved ... I never lost ..." (Butler, 138). And since language was not there to teach them that they were in love, a final moment of homicidal madness, mania and death instinct almost concludes funeral rites. Almost - as the last few lines are devoted to symbolic grace, a moonbeam and a flower which seal the maid's mourning of her daughter. Djondge's journey to the shores 
of evil and loneliness is sealed by the inevitable resignation to the symbolic order, to the anticipated good, to the Christian and patriotic end.

What is djondge? For a certain gay Israeli speech community djondge stands for penis. But this does not imply that djondge is phallus. The phallus, explains Deleuze, is a projected image, which bestows a new force on the child's penis ${ }^{34}$. The Phallus organizes the body's erogenous zones into a unified body, a unified order. But the same Phallus designates, on the contrary, a lack in the mother. This discovery threatens the child in an essential manner. The child seeks to correct the wrong, to retrieve and make present the father through the phallus. The problem with this attempt to make present is that in wishing to summon the father back and to make him present, the child betrays the paternal essence of withdrawal. This essence could not be found but only as if recovered - recovered in absence and in forgetfulness but never given in a simple presence of the "thing" which would eliminate forgetting. The structure of that which on the one hand has always been there, but on the other is not present, turns the phallus into the paradoxical element or object $=x$, missing always its own equilibrium, at once excess and deficiency, never equal, missing its own resemblance, its own identity, its own origin, its own place, and always displaced in relation to itself. ... the empty square ... and a supernumerary object ${ }^{35}$.

The symbolic order, therefore, does not stand on firm grounds, or any grounds at all for that matter. The symbolic order is organized around the phallus, whose authority is postulated in advance, but cannot be validated. But it is precisely this structure, acknowledging authority while giving up presence (in Lacanian: symbolic castration), which bestows upon the subject its power. Castration is the very gap between what I immediately am and the symbolic mandate which confers on me this "authority." In this precise sense, far from being the opposite of power, it is synonymous with power; it is that which confers power on me. And, one has to think of the phallus not as the organ which immediately expresses the vital force of my being, my virility, etc., but, precisely, as such an insignia, as a mask which I put on in the same way a king or judge puts on his insignia - phallus is an

\footnotetext{
${ }^{34}$ Gilles Deleuze, The logic of Sense (Mark Lester \& Charles Stivale, trans., Columbia University Press, 1990): 205-206.

${ }^{35}$ Gilles Deleuze, The logic of Sense (Mark Lester \& Charles Stivale, trans., Columbia University Press, 1990): 228.
} 
"organ without a body" which I put on, which gets attached to my body, without ever becoming its "organic part," namely, forever sticking out as its incoherent, excessive supplement ${ }^{36}$. Without the assumption of authority which is not subject to validation it is impossible to integrate into the symbolic order. She, who does not assimilate that assumption, is excluded.

Djondge, however, has a completely different structure. We have already seen that it cannot constitute anything for long. Its failure is foretold. Displacing and deferring melancholic identification has little endurance. Djondge's technique is nothing but a desperate attempt to flee what we already know will catch us. Djondge's technique is temporary. Moreover, this technique is contingent. It is not something necessary in order to integrate into any given order. But one should not infer from its contingency that it is contingent on a subject's decision. None of us would choose to lose a loved one, and if we do lose a loved one, our relation towards deferring mourning or declaring it, our relation towards identification with the lost object or identification with its enemies - these are not relations of conscious choice. This decision is not made by the subject, because, as Freud and Butler make perfectly clear, these decisions are those which constitute the subject. These decisions are pre-subjective. A djondge is not a source of authority, but a redistribution of authorities.

We know that eventually it is not the djondge, but the symbolic order constituted around the phallus which will prevail. Any attempt to work outside it is not stable and not sane. The symbolic order is precisely that which bestows an external force upon subjects, that which limits and empowers the real body. And but we who "... don't know what they are saying" ${ }^{37}$, we are excluded from accessing the phallus. We have to settle for a djondge. A djondge, unlike the phallus, can be made present, but it still yields nothing: neither order, nor authority, nor community. It is pointless. It is a diversion. It is not a partial object, it is a temporary object of jouissance and of despair. If we catch it, it will wither or explode; it cannot be held on to. And if it disappears and returns, if it is found again as that which has always been there, if it constitutes an order through the resonance of keeping one step ahead of itself, if we find ourselves flying back and forth between the mountains and the ocean with pebbles in our beaks, if djondge

\footnotetext{
${ }^{36}$ Slavoj Žižek, Organs without bodies: Deleuze and consequences (Routledge, 2004): 87.

${ }^{37}$ Jacques Lacan quoted by Luce Irigaray, "Così fan tutti", This sex which is not one (Catherine Porter \& Carolyn Burke, trans., Cornell University Press, 1985): 90.
} 
returns in this manner, if it constitutes an order of perpetual pursuit, then djondge did not return at all. Then we have forsaken djondge, and returned to the scar of castration, to the phallus, to the old symbolic order. Because that is precisely, as Deleuze explained above, how the phallus works. A djondge is a bypass route or a dead-end road. If we follow it we may have to retrace our steps, perhaps find ourselves back on the main road, or we may end up lost nowhere.

What is the point, then, of studying this queer political technique, the technique of Djondge, if we cannot choose it, and if it is bound to fail? What is the point of considering that which will get us nowhere, or take us back to where we had already been? This question is sensible only if we decide not to take into account the immediate, short-term impact of Djondge's technique, an effect which should not be disparaged. But, setting this important impact aside for whatever is left of this text, I shall quote two responses, both of which deserve a much more detailed analysis than I can give them here. The first reads: Whoever does not feel such heat in the floor that he'll gladly / Exchange it for any other, rather than stay, to that man / I have nothing to say. Thus replies Brecht in The Buddha's parable of the burning house ${ }^{38}$.

To those who had not asked, the Buddha addressed this parable:

'Lately I saw a house. It was burning. The flame

Licked the roof. I went up close and observed

That there were people still inside. I entered the doorway and called

Out to them that the roof was ablaze, so exhorting them

To leave at once. But those people

Seemed in no hurry. One of them,

While the heat was already scorching his eyebrows,

Asked me what it was like outside, whether it wasn't raining,

Whether the wind wasn't blowing, perhaps, whether there was

Another house for them, and more of this kind. Without answering

I went out again. These people here, I thought,

\footnotetext{
${ }^{38}$ Bertolt Brecht, Tales from the calendar (Michael Hamburger, trans., Methuen, 1961): $31-32$.
} 


\section{Must burn to death before they stop asking ques- tions. And truly, friends}

This urgent appeal, as befitting Brecht, is very compelling. However, what if the roof has only very recently caught on fire? Shouldn't we pack some provisions before we run out screaming? Surely we have a few moments more. And if the burning house is not a house at all, but a hall of mirrors, how can find our way out? Even if there is a way out, how can we find it among the blazing mirrors? And what if the mirrors would not be in the world, simply, included in the totality of all onta and their images, but that thing "present," on the contrary, would be in them. Imagine that the mirrors (shadows, reflections, phantasms, etc.) would not be comprehended within the structure of the ontology and the myth of the cave - which also situates the screen and mirror - but would rather envelop it in its entirety, producing here or there a particular, extremely determinate effect ${ }^{39}$. Picture all this ablaze. How do we get out now?

The second response is quoted from Benjamin. If the existence of violence ${ }^{40}$ outside the law, as pure immediate violence, is assured, this furnishes the proof that revolutionary violence, the highest manifestation of unalloyed violence by man, is possible, and by what means. It is easy to mistake the kind of hope which Benjamin presents, so he quickly clarifies: Less possible and also less urgent for human kind, however, is to decide when unalloyed violence has been realized in particular cases ... because the expiatory power of violence is not visible to men $^{41}$.

This very violence which is law-destroying, which boundlessly destroys, which expiates, which strikes, which is lethal without spilling

\footnotetext{
${ }^{39}$ Jacques Derrida, "Dissemination", Dissemination (Barbara Johnson, trans., University of Chicago Press, 1981): 324.

${ }^{40} \mathrm{I}$ push the issue of violence aside in this paper, and I may be at fault in this respect. But Djondge's political technique is not necessarily violent or non-violent. Violence may follow from standard melancholic identification just as it can follow from Djondge's technique of displacing and deferring melancholic identification. The crucial factor here is the violence incarnated in the object and performance of identification. Djondge's technique intensifies the conflict in the forming subject, and therefore charges it with power. But power, which we have already defined as permanent provocation, is not necessarily destined to be actualized in the form of violence.

${ }^{41}$ Walter Benjamin, "Critique of Violence", Selected Writings (Marcus Bullock \& Michael W. Jennings, ed., Belknap Press, 1996-2003): Vol. 1, 300.
} 
blood $^{42}$, even if we are convinced that it exists, we shall never be able to identify it. A clearer statement concerning the structure of Benjamin's revolutionary hope can be found in his On the concept of history. We know that the Jews were prohibited from inquiring into the future ... This does not imply, however, that for the Jews the future became homogeneous, empty time. For every second was the small gateway in time through which the Messiah might enter ${ }^{43}$. This kind of hope encourages us to follow aimless routes (such as, but not exclusively, Djondge's technique), as it might be such routes where a small gateway should open up. But even if we accept this form of hope, and unalloyed violence erupts through the small gateway, would it not, like djondge, die-out as quickly as it lit-up, inscribing us back into symbolic order (or in Benjamin's language, mythical law)?

Facing this discouraging body of knowledge, the hope which might motivate into desperate resistance is not the hope that banging my head against windmills will make a small dent, where a small gateway might open. The hope which drives me to action, when I know I don't stand a chance, is not even the hope that the blood which will flow from my head as I bash my head against the wall will carve a small route, and force open a small gateway. The hope which drives me into action and resistance, even though I know action and resistance are hopeless, is the hope that I am wrong.

Davidson formulated his charity principle thus: if we want to understand others, we must count them right in most matters ${ }^{44}$. If we were trying to understand "what does it mean?" or "how does it work?" we should have perhaps stuck to this principle, which has some truthful charity $^{45}$ to it. But a grace beyond charity, amazing grace, capable of responding to the question "what can we do with it?", capable of conferring on us some hope against the uncontestable endurance of an oppressive order, such grace may turn out to be found precisely in the assumption that, perhaps, I am wrong.

\footnotetext{
${ }^{42}$ Walter Benjamin, "Critique of Violence", Selected Writings (Marcus Bullock \& Michael W. Jennings, ed., Belknap Press, 1996-2003): Vol. 1, 297.

${ }^{43}$ Walter Benjamin, "On the concept of history", Selected writings (Marcus Bullock \& Michael W. Jennings, ed., Belknap Press, 1996-2003): Vol. Iv, 397. I owe my reading in Benjamin to two of my teachers, Prof. Adi Ophir and Prof. Shlomo Sand, two different readings set against the background of Derrida's Force of law. Shlomo Sand published his account in his book The historian, time, and imagination (Am Oved Press, 2004) (Hebrew) and Les mots et la terre (Fayard, 2006) (French).

${ }^{44}$ Donald Davidson, "On the very idea of a conceptual Scheme", Inquiries into Truth and Interpretation (Clarendon Press, 1984): 197.

${ }^{45}$ In Hebrew the term "truthful charity" is an idiom for funeral rites.
} 
Amazing grace might be found in assuming that perhaps this endurance, along with the formative axiom and/or well founded structural conclusion which state that the order of the Other must stand firm - that these are perhaps all mistakes. Our knowledge is so scarce and volatile; why take it for an accomplished fact exactly where it extinguishes our hope? Djondge's political technique does not seek to find mistakes in the established order, nor does it seek to expose an error in our comprehension of the world. Most definitely, Djondge's technique does not demand from us to overcome such errors or mistakes. Djondge's queer political technique attempts to wander along the routes of identification in order to retrace, reproduce and disseminate mistakes.

You should not try to find if an idea is just or correct. You should look for a completely different idea, elsewhere, in another area, so that something passes between the two which is neither in one nor the other ${ }^{46}$. That is to wander between ideas, even if this wandering is an errance. In fact, we needn't even look for a completely different idea. The space of repetitions, reproductions, distributions of acknowledged mistakes and old ideas along, through and against the symbolic order is so wildly fluid and diverse, that this space alone is enough to reduce despair of struggle to absurd; that these repetitions, reproductions, distributions alone are enough to spread out a net of motions so fine, so welcoming, so hospitable and dense, so that — who dare say otherwise? we are able and willing to live our way through.

Roy Wagner, The Cohn Institute for the history And Philosophy of SCIEnCE AND IDEAs, Tel-Aviv University, RWAGNER@MtA.AC.IL.

\footnotetext{
${ }^{46}$ Gilles Deleuze \& Claire Parnet, Dialogues (Hugh Tomlinson and Barbara Habberjam, trans., Columbia University Press, 1987): 10.
} 